\title{
Cyst-motile stage relationship and molecular phylogeny of a new freshwater dinoflagellate Gymnodinium plasticum from Plastic Lake, Canada
}

\author{
Wang $\mathrm{Na}{ }^{1}$, Luo Zhaohe ${ }^{1}$, Mertens Kenneth ${ }^{2}$, Mccarthy Francine M. G. ${ }^{3}$, Gu Li ${ }^{1}$, Gu Haifeng ${ }^{1,{ }^{*}}$ \\ ${ }^{1}$ State Ocean Adm, Inst Oceanog 3, Xiamen, Peoples R China. \\ 2 IFREMER, Stn Biol Marine, LER BO, Concarneau, France. \\ ${ }^{3}$ Brock Univ, Earth Sci, St Catharines, ON, Canada. \\ * Corresponding author ; Haifeng, Gu, email address : quhaifeng@tio.org.cn
}

\begin{abstract}
:
The dinophyceaen genus Gymnodinium was established with the freshwater species G. fuscum as type. According to Thessen et al. (2012), there are 268 species, with the majority marine species. In recently published molecular phylogenies based on ribosomal DNA sequences, Gymnodinium is polyphyletic. Here, a new freshwater Gymnodinium species, G. plasticum, is described from Plastic Lake, Ontario, Canada. Two strains were established by incubating single cysts, and their morphology was examined with light microscopy and scanning electron microscopy. The cyst had a rounded epicyst and hypocyst with a wide cingulum and smooth surface. Vegetative cells were characterized by an elongated nucleus running vertically and a deep sulcal intrusion. The apical structure complex was horseshoe-shaped and consisted of two pronounced ridges with a deep internal groove, encircling $80 \%$ of the apex. Small subunit ribosomal DNA (SSU rDNA), large subunit ribosomal DNA (LSU rDNA) and internal transcribed spacer (ITS) sequences were obtained from cultured strains. Molecular phylogeny based on concatenated SSU, LSU and ITS sequences supports the monophyly of the Gymnodiniales sensu stricto clade but our results suggest that many Gymnodinium species might need reclassification. Gymnodinium plasticum is closest to Dissodinium pseudolunula in our phylogeny but distant from the type species G. fuscum, as are the other gymnodiniacean taxa.
\end{abstract}

Keywords : apical structure complex, cyst, Gymnodiniales sensu stricto, Gymnodinium fuscum 


\section{INTRODUCTION}

About 2,300 dinoflagellate species have been described in the world (Gómez 2012), only around 350 of them inhabiting freshwater (Mertens et al. 2012), suggesting that only a small fraction of marine dinoflagellate lineages has succeeded in crossing the marine-freshwater boundary (Logares et al. 2007b). Some genera (e.g. Peridinium Ehrenberg, Peridiniopsis Lemmermann) are exclusively freshwater and do not have marine representatives. Most transitions to freshwater appear to have occurred long ago based on molecular evidence (Logares et al. 2009), possibly because it would have been easier for marine immigrants to transition into freshwater environments before locally adapted communities with high species richness were established (Levine \& D’Antonio 1999). Recent transitions have been reported in the phototrophic brackish Apocalathium malmogiense (G. Sjöstedt) Craveiro, Daugbjerg, Moestrup \& Calado (=Scrippsiella hangoei (J. Schiller) J. Larsen) / freshwater Apocalathium aciculiferum (Lemmermann) Craveiro, Daugbjerg, Moestrup \& Calado (=Peridinium aciculiferum Lemmermann), which share identical small subunit (SSU), large subunit (LSU) ribosomal DNA (rDNA) and internal transcribed spacer (ITS) region sequences (Logares et al. 2007a; Craveiro et al. 2016).

A few dinoflagellates are known to inhabit both marine and freshwater, e.g. Huia caspica (Ostenfeld) H. Gu, K.N. Mertens, T. Liu, Durinskia baltica (Levander) Carty \& Cox, Kolkwitziella acuta Lindemann, probably due to recent transitions (Mertens et al. 2015; Gu et al. 2016).

The genus Gymnodinium F. Stein was erected by F. Stein (1878) with the 
freshwater species Gymnodinium fuscum F. Stein as type (see Hansen et al. 2000 for more details). Gymnodinium was broadly defined and encompassed athecate dinoflagellates from both marine and freshwater whose cingulum displacement was less than $20 \%$ of the cell length (Kofoid \& Swezy 1921). This initial classification based on cingulum displacement is now considered arbitrary and later more emphasis was placed on the systematic significance of the apical groove (Takayama 1985). Gymnodinium was then revised as possessing a horseshoe-shaped apical groove, a nuclear envelope with vesicular chambers and a nuclear or dorsal fibrous connector (NFC) (Daugbjerg et al. 2000). These revisions were based on detailed examinations of the freshwater species G. fuscum (the type species of Gymnodinium). Hansen et al. (2000) point out that G. fuscum lacks a transverse striated flagellar root and striated collars around the flagellar canals, which are rarely found in dinoflagellates; therefore, many species of Gymnodinium might need reclassification.

Moestrup et al. (2014) renamed the apical groove as apical structure complex (ASC) and revealed that the ASC comprises three elongated vesicles in Levanderina fissa (Levander) Ø. Moestrup, P. Hakanen, G. Hansen, N. Daugbjerg \& M. Ellegaard. Such vesicles have also been reported in other gymnodinioid species, such as Gymnodinium impudicum (S. Fraga \& I. Bravo) G. Hansen \& Moestrup, Barrufeta bravensis N. Sampedro \& S. Fraga and B. resplendens (Hulburt) H. Gu, Z. Luo \& K.N. Mertens (Sampedro et al. 2011; Gu et al. 2015). The morphological details of the ASC in G. fuscum, however, were not investigated in detail (Hansen et al. 2000). A review of the literature led Thessen et al. (2012) to propose that there are 268 
extant Gymnodinium species, with only 66 from freshwater habitats. Most of these species, however, were described long ago without much detail. Therefore, once detailed examinations were conducted using modern techniques, some were transferred to other genera. The freshwater Gymnodinium limneticum Wołoszyńska and G. palustre A.J. Schiller were transferred into Spiniferodinium Horiguchi \& Chihara because they exhibit capsoid cells as predominant life-history stage (Kretschmann et al. 2015), and the freshwater G. acidotum Nygaard and G. aeruginosum F. Stein were transferred into Nusuttodinium Takano \& Horiguchi as they steal a temporary chloroplast by preying on cryptophytes (Takano et al. 2014). Molecular phylogeny supports the transfer of these freshwater Gymnodinium species and supports a well resolved Gymnodiniales sensu stricto clade, consisting of Gymnodinium and a variety of genera, e.g. Barrufeta N. Sampedro \& S. Fraga, Dissodinium Klebs, Gyrodiniellum N.S.Kang, H.J. Jeong \& Moestrup, Lepidodinium Watanabe, Suda, Inouye, Sawaguchi \& Chihara, Nematodinium C.A. Kofoid \& O. Swezy, Paragymnodinium N.S. Kang, H.J. Jeong, Moestrup \& W. Shin, Polykrikos Bütschli, Spiniferodinium, Warnowia Lindemann (Hoppenrath \& Leander 2007; Hoppenrath et al. 2009; Kang et al. 2010; Hansen \& Daugbjerg 2011; Kang et al. 2011; Kretschmann et al. 2015). To fully understand the genus Gymnodinium, it is essential to incorporate more sequences from freshwater species. Sequences are currently available for only three freshwater Gymnodinium species, i.e. G. fuscum, G. baicalense N.L. Antipova and G. impatiens Skuja, and the closest relative of $G$. fuscum is not clear (Kretschmann et al. 2015). Moreover, the SSU sequence of $G$. 
impatiens is close to Gyrodinium and falls outside the Gymnodiniales sensu stricto clade (Kang et al. 2014).

Approximately 84 freshwater dinoflagellates are known to produce cysts, including 16 Gymnodinium species (Mertens et al. 2012). The cyst morphology of Gymnodinium species is extremely variable, ranging from round to ellipsoidal, with or without ornamentations. Some (e.g. Gymnodinium dodgei Sarma \& Shyam) have been transferred based on cyst morphology (Luo et al. 2016), but cyst-motile cell relationship of additional Gymnodinium species is needed. Here we isolate two cysts from surface sediments collected from Plastic Lake, Canada and establish the cyst-motile cell relationship of a new Gymnodinium species. We also sequence the SSU, LSU rDNA and ITS sequences to infer its phylogenetic position by concatenating the sequences.

\section{MATERIAL AND METHODS}

Surface sediment samples were collected from ca. $3 \mathrm{~m}$ water depth on the lakebed of Plastic Lake, Canada $\left(45^{\circ} 18.34^{\prime} \mathrm{N}, 78^{\circ} 83.29^{\prime} \mathrm{W}\right)$ using a grab sampler. The sediment samples were stored in the dark at $4^{\circ} \mathrm{C}$ until further treatment. Approximately $5 \mathrm{~g}$ of wet sediment were mixed with $20 \mathrm{~mL}$ of sterilized MilliQ water and sonicated for 2 min (100 watts) to dislodge detrital particles. Single cysts were isolated by means of drawn-out Pasteur pipettes under an AE30 inverse microscope (Motic, Xiamen, China) and incubated in 96 well culture plate filled with $300 \mu \mathrm{L}$ carefoot medium (Carefoot 1968) at $20^{\circ} \mathrm{C}, 90 \mu \mathrm{E} \mathrm{m}^{-2} \mathrm{~s}^{-1}$ under a $12: 12 \mathrm{~h}$ light: dark cycle (hereafter called 
"standard culture conditions"). Germinated cells were maintained under standard culture conditions and two strains (TIO826 and TIO827) were established.

Vegetative cells of both strains were examined under a Zeiss Axio Imager microscope (Carl Zeiss, Göttingen, Germany) equipped with both differential interference illumination and epifluorescence. Light micrographs were obtained using a Zeiss Axiocam HRc digital camera. Approximately $1 \mathrm{~mL}$ of live, healthy culture in mid exponential growth phase was transferred to a $1.5 \mathrm{~mL}$ microcentrifuge tube, and DAPI (4',6-diamidino-2-phenylindole dihydrochloride) stain (Sigma-Aldrich, St. Louis, Missouri, USA) was added at a final concentration of $10 \mu \mathrm{g} \mathrm{mL}^{-1}$. The cells were viewed and photographed through a Zeiss Filterset (emission: BP 365-445; beamsplitter: FT 395). Cells in mid exponential growth phase were fixed with 5\% Lugol's solution, and cell size was measured at $400 \times$ magnification. Forty cells were measured for strains TIO826 and TIO827.

Mid-exponential batch cultures $(600 \mu \mathrm{L})$ were fixed for $1 \mathrm{~h}$ at $4{ }^{\circ} \mathrm{C}$ with $4 \% \mathrm{OsO}_{4}$ ( $200 \mu \mathrm{L})$ prepared with filtered MilliQ water. The material was then dehydrated in an ethanol series (once in 10, 30, 50, 70 and 90\%, followed by three times in 100\%; 10 min at each step), critical point dried (K850 Critical Point Dryer, Quorum/Emitech, West Sussex, UK), sputter-coated with gold, and examined using a Zeiss Sigma FE (Carl Zeiss Inc., Oberkochen, Germany) scanning electron microscope.

Single cells were isolated and washed three times with sterilized bi-distillate water and were used as the template to amplify about 1,430 bp of the LSU rRNA gene (D1-D6 domains), using the primers D1R (forward, 
5'-ACCCGCTGAATTTAAGCATA-3') (Scholin et al. 1994), 28-1483R (reverse, 5'-GCTACTACCACCAAGATCTGC-3') (Daugbjerg et al. 2000), 1,740 bp of the SSU rRNA gene, using the primers SR1 (forward, 5'-TACCTGGTTGATCCTGCCAG-3') and SR12b (reverse, 5'-CGGAAACCTTGTTACGACTTCTCC-3') (Takano \& Horiguchi 2006), and 600 bp of the total ITS1-5.8S-ITS2, using the primers ITSA (forward, 5'-CCTCGTAAC AAGGHTCCGTAGGT-3'), ITSB (reverse, 5'-CAGATGCTTAARTTCAGCRGG) (Adachi et al., 1996). A $50 \mu \mathrm{L}$ PCR cocktail containing $0.2 \mu \mathrm{M}$ forward and reverse primer, PCR buffer, $50 \mu \mathrm{M}$ dNTP, $1 \mathrm{U}$ of Taq DNA polymerase (Takara, Dalian, China) was subjected to 35 cycles using a Mastercycler PCR (Eppendorf, Hamburg, Germany). The PCR protocol was identical to that of (Gu et al. 2015). PCR products were sequenced directly in both directions using the ABI Big-Dye dye-terminator technique (Applied Biosystems, Foster City, CA, USA), according to the manufacturer's recommendations. New sequences were deposited in GenBank with accession numbers from KY688184 to KY688189.

New sequences obtained in this study were incorporated into those of closely related species available in the GenBank and that of outgroup taxa were first aligned using 'BioEdit' v7.0.0 (Hall 1999), and then using Mafft (Katoh et al. 2005) (http://mafft.cbrc.jp/alignment/server/). The program JModelTest (Posada 2008) was used to select the most appropriate model of molecular evolution with Akaike information criterion (AIC). This test chose the general time-reversible (GTR) model of substitution (Rodriguez et al. 1990) following a gamma distribution shape 
parameter (0.4080) $(\mathrm{GTR}+\mathrm{G})$. Maximum likelihood-based analyses were conducted using with RAxML v7.2.6 (Stamatakis et al. 2008) on the T-REX web server (Boc et al. 2012). The Gamma model was selected and 1,000 bootstraps were carried out.

A Bayesian reconstruction of the data matrix was performed with MrBayes 3.0b4 (Ronquist \& Huelsenbeck 2003) using the best-fitting substitution model. Four Markov chain Monte Carlo (MCMC) chains ran for five million generations, sampling every 1,000 generations, with an appropriate burnin (10\%). A majority rule consensus tree was created in order to examine the posterior probabilities of each clade.

\section{RESULTS}

\section{Gymnodinium plasticum N. Wang, Z. Luo, K. N. Mertens, F.M.G.} McCarthy, H. Gu sp. nov.

\section{Diagnosis}

Vegetative cells with rounded epicone and hypocone, 25.5-36.1 $\mu \mathrm{m}$ long, and 21.2-27.6 $\mu \mathrm{m}$ wide, inhabiting fresh water. Chloroplasts in the periphery forming a network and nucleus elongated longitudinally. There are $9-10,5$ and $8-10$ rows of vesicles on the epicone, cingulum and hypocone, respectively. The cingulum is deeply incised with a descending displacement of approximately one cingular width. The sulcus intrudes deeply into the epicone. There is a circular orange stigma in the sulcal area. The apical structure complex is horseshoe shaped encircling the apex around $80 \%$. The ASC consists of two pronounced ridges and a deep groove inside. The cyst has a rounded epi- and hypocyst, 30.8-40.6 $\mu \mathrm{m}$ long, 28.0-35.4 $\mu \mathrm{m}$ wide and 
23.8-29.5 $\mu \mathrm{m}$ deep. The cyst is rectangular in lateral view and trapezoidal in polar view. The cyst has a wide cingulum and covered by a thin wall with smooth surface.

\section{Holotype}

SEM stub of strain TIO826 deposited at Third Institute of Oceanography, SOA,

Xiamen 361005, China.

Type locality

Plastic Lake $\left(45^{\circ} 18.34^{\prime} \mathrm{N}, 78^{\circ} 83.29^{\prime} \mathrm{W}\right)$, a small oligo-mesotrophic holomictic lake dating back to retreat of the Laurentide Ice Sheet from south-central Ontario, Canada, ca. 11,000 years ago.

\section{Etymology}

'plasticum' derives from Plastic Lake, refers to the type locality.

\section{GenBank accession number sequences}

KY688188 (SSU), KY688184 (LSU) and KY688186 (ITS) of strain TIO826.

\section{Description}

The vegetative cells of Gymnodinium plasticum (strain TIO826) are 25.5-36.1 $\mu \mathrm{m}$ long $($ mean $=30.2 \pm 2.5 \mu \mathrm{m}, \mathrm{n}=42)$ and $21.2-27.6 \mu \mathrm{m}$ wide $($ mean $=24.7 \pm 2.5 \mu \mathrm{m}, \mathrm{n}$ =42). Vegetative cells of strain TIO827 are 25.0-34.1 $\mu \mathrm{m}$ long (mean $=29.7 \pm 2.4 \mu \mathrm{m}$, $\mathrm{n}=40)$ and $19.8-26.4 \mu \mathrm{m}$ wide $($ mean $=23.5 \pm 2.6 \mu \mathrm{m}, \mathrm{n}=40)$. They share the same cell morphology with TIO826. They display a characteristic golden colour (Fig. 1), and only a small fraction can form paired chains in optimal conditions (Fig. 2). Many band-like chloroplasts are interconnected to form a network in the periphery of the cell (Figs 3, 4). A few round starch rings, presumably stalked pyrenoids are located 
near the cingulum and a circular orange stigma is present in the sulcal area (Fig. 5). The nucleus is elongated running nearly vertically, and occupies most of the cell spanning from the epicone to the hypocone (Figs 3,6). The epicone is nearly equal in size to the hypocone. Both the epicone and the hypocone are rounded (Figs 3-5). The cingulum is deeply incised and has sharp edges, with a descending displacement of approximately one cingular width. The sulcus is narrow and deeply excavated, especially in the intercingular area due to the projection of right epicone (Fig. 1).

Under SEM, the cells show amphiesmal vesicles which are either pentagonal or hexagonal (Figs 7-10). As many as seven amphiesmal pores (around $0.5 \mu \mathrm{m}$ in diameter) are present in the epicone and hypocone (Fig. 9). There are around 9-10, 5 and 8-10 rows of vesicles on the epicone, cingulum and hypocone, respectively. The sulcus intrudes around $60 \%$ of the epicone where it connects to the onset of the apical structure complex (ASC) (Figs 7, 8). The ASC is horseshoe-shaped and joins the sulcal intrusion, forming the shape of a question mark. The ASC runs anticlockwise, and encircles the apex around $80 \%$. The ASC consists of two pronounced ridges and a deep groove inside (Figs 10,12). The outer ridge is ornamented with numerous small knobs (Figs 13, 14).

The cyst from the field has a rounded epicyst and a rounded to conical hypocyst (Figs 15, 16), around 30.8-40.6 $\mu \mathrm{m}$ long, 28.0-35.4 $\mu \mathrm{m}$ wide and 23.8-29.5 $\mu \mathrm{m}$ deep $(n=6)$. The cyst wall is thin, and is underlain by a thicker endospore layer. The cyst is rectangular in lateral view and trapezoidal in apical and antapical view and is excavated on the ventral side (Figs 17, 18). The cyst is filled with brown granules and 
there is a conspicuous red accumulation body inside and a spherical nucleus (Figs 15-17). The cyst has a wide cingulum, accounting for approximately $40 \%$ of the cyst length, and has a smooth surface (Figs 19, 20). We could not observe the archeopyle.

\section{Molecular phylogenetics}

Two strains of Gymnodinium plasticum share identical SSU, LSU and ITS sequences, and they differ from G. fuscum at 40, 193 and 233 positions $(97.64 \%, 74.20 \%$ and 61.42\% similarity), respectively. Gymnodinium plasticum differs from Dissodinium pseudolunula Swift ex Elbrächter \& Drebes at 40, 133 positions (96.58\% and 86.66\% similarity) of partial SSU and LSU sequences, and differs from G. baicalense at 7 and 69 positions ( $99.0 \%$ and $80.5 \%$ similarity) of partial SSU (709 bp) and ITS sequences.

Maximum likelihood and Bayesian inference generate identical trees (Fig. 21) by using concatenated data from SSU, ITS and LSU sequences. Gymnodinium plasticum and Dissodinium pseudolunula form a clade with maximum bootstrap support (100), but low Bayesian posterior probability (0.73), which is a sister clade comprising $G$. baicalense, G. aureolum (Hulburt) G. Hansen, G. corollarium A. M. Sundström, Kremp \& Daugbjerg, Chytriodinium sp., and Pheopolykrikos beauchampii Chatton with maximum bootstrap support (100), but low Bayesian posterior probability (0.67). They are nested within the well resolved Gymnodiniales sensu stricto clade (1.0/100) comprising amongst others Barrufeta, Polykrikos, Nematodinium, Nusuttodinium, Spiniferodinium, Lepidodinium, Paragymnodinium, Warnowia, Nematodinium, Gyrodiniellum and Gymnodinium. Gymnodinium fuscum diverges earliest in the Gymnodiniales clade but is not well supported. 


\section{DISCUSSION}

The equatorial cingulum with slight displacement and the horseshoe-shaped ASC justifies classifying our strains in the genus Gymnodinium (Kofoid \& Swezy 1921; Daugbjerg et al. 2000). Under light microscope, G. plasticum was characterized by a deep sulcal intrusion and an elongated nucleus running nearly vertically. Few freshwater species reported are similar to G. plasticum (Table 1). Both Gymnodinium limitatum Skuja and G. mirabile Penard have deep sulcal intrusions, but G. mirabile is much larger (48-68 $\mu \mathrm{m}$ long, 46-62 $\mu \mathrm{m}$ wide) and has a small nucleus located in the hypocone (Pénard 1891, plate V, fig. 1). Gymnodinium limitatum has a spherical nucleus and produce spherical cysts (Skuja 1956, Tafel LXI, figs 29-31). Gymnodinium impatiens has no sulcal intrusion and is much smaller and produces ellipsoidal cysts (Skuja 1964, Tafel LXVI, figs 31-34). Gymnodinium uberrimum (Allman) Kofoid \& Swezy is of similar size and can form paired cell chains too but its nucleus is rounded and small and it has slight sulcal intrusion (Allman 1855, pl. 3, figs. 9-17). Gymnodinium plasticum is also similar to G. excavatum Nygaard but the latter has a pronounced eyespot (Nygaard 1945), thus was considered as a synonym of Biecheleria pseudopalustris (J. Schiller) Moestrup, Lindberg \& Daugbjerg (Moestrup et al. 2009). Gymnodinium plasticum differs from G. fuscum in the shape of hypocone and nucleus, the configuration of chloroplasts and the cyst morphology (Hansen et al. 2000). Gymnodinium plasticum is also similar to some marine athecate species in general shape and sulcal intrusion, including Gymnodinium mundulum Campbell, Gymnodinium aureolum , Gymnodinium polycomma Larsen, Gymnodinium 
corollarium and G. litoralis A. Reñé (Campbell 1973; Larsen 1994; Sundström et al. 2009; Hansen et al. 2000; Reñé et al. 2011), but differ in the cell size, elongated nucleus running vertically, and banded chloroplasts forming a network (Table S1).

The cyst of G. plasticum resembles some previously described cysts. It superficially resembles the cyst of the freshwater species Woloszynskia tylota (H. Mapletoft, M. Montgomery, J. Waters \& P. Wells) B.T. Bibby \& J.D. Dodge in the general shape and a wide cingulum, but differs in the lack of a pronounced apical horn and eight additional protuberances in the four corners (Mapletoft et al. 1966). It also somewhat resembles the cyst of the freshwater species G. chiastosporum (Harris) Cridland, but differs in the absence of projections at each edge (Harris 1940). The cyst is also different from that of the freshwater species Glenodinium segriense Dangeard, which has a pronounced apical and antapical horn (Dangeard 1939). The cyst of G. plasticum also somewhat resembles that of the marine species G. trapeziforme Attaran-Fariman \& Bolch (Attaran-Fariman et al. 2007), but differs in the absence of microreticulation on the surface and in its transparent color (as opposed to brown). Based on the differences from previously reported motile cells and cysts, we consider our strains to belong to a new Gymnodinium species, Gymnodinium plasticum.

The ASC of Gymnodinium plasticum consists of a deep groove surrounded by two pronounced ridges. Such a type of ASC was also observed in the marine species $G$. trapeziforme (Attaran-Fariman et al. 2007), G. aureolum (Tang et al. 2008), G. corollarium (Sundström et al. 2009), G. catenatum Graham, and G. microreticulatum Bolch \& Hallegraeff (Gu et al. 2013), as well as in the freshwater species G. fuscum, G. 
mirabile, and G. obesum Schiller (Hansen \& Flaim 2007). Species from closely related genera, e.g. Polykrikos lebourae Herdman (Hoppenrath \& Leander 2007), Nematodinium armatum (Dogiel) Kofoid \& Swezy (Takayama 1985), Spiniferodinium limneticum (Wołoszyńska) Kretschmann \& Gottschling (Kretschmann et al. 2015), Nusuttodinium acidotum (Nygaard) Takano \& Horiguchi (Takano et al. 2014) also have a similar ASC, which was tentatively named "Type I". Another kind of ASC consists of three elongated vesicles, which might correspond to the two prominent ridges and a deep groove inside observed in Gymnodinium plasticum. This ASC has been reported for Barrufeta bravensis, B. resplendens, G. litoralis, and Gymnodinium impudicum (Reñé et al. 2011; Sampedro et al. 2011; Gu et al. 2015). These vesicles can be ornamented with numerous small knobs (Sampedro et al. 2011; Moestrup et al. 2014; Gu et al. 2015) or without small knobs (Reñe et al. 2011). The last kind of ASC (“Type II”) consists of one row of amphiesmal vesicles with numerous small knobs, reported in Gymnodinium smaydae Kang, Jeong \& Moestrup (Kang et al. 2014) and Gyrodiniellum shiwhaense Kang, Jeong \& Moestrup (Kang et al. 2011).

The shape of ASC can be much more variable, although the term "horseshoe-shaped" was generally used to describe ASC in Gymnodinium species. The shape of ASC can be circular (e.g. Gymnodinium mirabile) (Hansen \& Flaim 2007), fish-hook shaped (e.g. Spiniferodinium limneticum) (Kretschmann et al. 2015), or Smurfcap-shaped (e.g. Barrufeta bravensis) (Sampedro et al. 2011). Even for species with an ASC of similar shape, the details can vary. For instance, G. impudicum has small knobs on each elongated vesicle, whereas Barrufeta bravensis only has 
small knobs on the middle row of vesicles (Sampedro et al. 2011).

Our molecular phylogeny generally supports previous results based on LSU or SSU sequences regarding the monophyly of Gymnodiniales sensu stricto clade (Reñé et al. 2011; Kang et al. 2014; Reñé et al. 2015). Kretschmann et al. (2015) demonstrated that Gymnodinium fuscum is distant from other Gymnodinium species using concatenated data of SSU, LSU ribosomal DNA, ITS sequences, mitochondrial and actin gene sequences although with low support, which is confirmed by our molecular phylogeny. As a result, nomenclature changes might be expected for many Gymnodinium species. This has been suggested previously as G. fuscum is unique in the ultrastructure detail, i.e. lack of a transverse striated flagellar root and striated collars around the flagellar canals (Hansen et al. 2000).

The close relationship between Dissodinium pseudolunula and Gymnodiniales sensu stricto species was reported by Kim et al. (2008), and here we further demonstrate that it is closest to G. plasticum, which might be explained by the fact that D. pseudolunula has Gymnodinium-like swarmers (Kofoid \& Swezy 1921; Swift 1973). They group together with G. baicalense, G. aureolum, G. corollarium, and Chytriodinium sp., encompassing both marine and freshwater species, with a lifestyle varying from autotrophic to parasitic. We follow Reñé et al. (2015) in using the Gymnodiniales sensu stricto clade to incorporate those species previously also known as Gymnodinium sensu stricto clade (Reñé et al. 2011; Kang et al. 2014). This clade incorporates three groups of freshwater species, supporting the idea that marine-fresh water transitions are infrequent (Logares et al. 2007b). The evolution of species like $G$. 
plasticum may have been facilitated during Quaternary deglaciations by the creation of numerous freshwater lakes lacking established ecosystems, as suggested by Levine and D'Antonio (1999).

According to the diagnosis by Daugbjerg et al. (2000), Gymnodinium is characterized by horseshoe-shaped ASC, nuclear chambers and a NFC (Daugbjerg et al. 2000). These features are also shared by Gymnoxanthella radiolariae T. Yuasa \& T. Horiguchi, and Lepidodinium viride M. M. Watanabe, S. Suda, I. Inouye Sawaguchi \& Chihara (Hansen et al. 2007; Yuasa et al. 2016). Therefore, the unequivocal definition of Gymnodinium might require more details from ASC and additional ultrastructure. Because our strains of Gymnodinium plasticum could not be maintained, it was not possible to obtain ultrastructural information; this will be the focus of future work.

\section{ACKNOWLEDGEMENTS}

We thank two anonymous reviewers and the responsible editor for constructive suggestions that improved the ms greatly. This work was supported by National Natural Science Foundation of China (41676117) and Bilateral International Cooperation Project of SOA (HC170301). We thank AM Krueger, Brock University, who assisted with field sampling.

\section{REFERENCES}

Adachi, M., Sako, Y., Ishida, Y., 1996. Analysis of Alexandrium (Dinophyceae) 
species using sequences of the 5.8S ribosomal DNA and internal transcribed spacer regions. J. Phycol. 32: 424-32.

Allmann, G. J. 1855. Observations on Aphanizomenon flosaqua, and a species of Peridinea. Quarterly J. Micros. Sci. 3: 21-5.

Attaran-Fariman, G., De Salas, M. F., Negri, A. P. and Bolch, C. J. S. 2007. Morphology and phylogeny of Gymnodinium trapeziforme sp. nov. (Dinophyceae): a new dinoflagellate from the southeast coast of Iran that forms microreticulate resting cysts. Phycologia 46: 644-56.

Boc, A., Diallo, A. B. and Makarenkov, V. 2012. T-REX: a web server for inferring, validating and visualizing phylogenetic trees and networks. Nucleic Acids Res. 40: W573-9.

Campbell, P. H. 1973. The phytoplankton of Gales Creek with emphasis of the taxonomy and ecology of estuarine phytoflagellates. $\mathrm{PhD}$ dissertation, University of North Carolina, Chapel Hill.

Carefoot, J. R. 1968. Culture and heterotrophy of the freshwater dinoflagellate, Peridinium cinctum fa. ovoplanum Lindeman. J. Phycol. 4: 129-31.

Craveiro, S. C., Daugbjerg, N., Moestrup, Ø. and Calado A. J. 2016. Studies on Peridinium aciculiferum and Peridinium malmogiense (= Scrippsiella hangoei): comparison with Chimonodinium lomnickii and description of Apocalathium gen. nov. (Dinophyceae). Phycologia 56: 21-35.

Dangeard, P. A. 1939. Second Mémoire sur la famille des Péridiniens. Le Botaniste 29: 267-309. 
Daugbjerg, N., Hansen, G., Larsen, J. and Moestrup, Ø. 2000. Phylogeny of some of the major genera of dinoflagellates based on ultrastructure and partial LSU rDNA sequence data, including the erection of three new genera of unarmoured dinoflagellates. Phycologia 39: 302-17.

Gómez, F. 2012. A checklist and classification of living dinoflagellates (Dinoflagellata, Alveolata). CICIMAR Oceánides 27: 65-140.

Gu, H., Liu, T., Vale, P. and Luo, Z. 2013. Morphology, phylogeny and toxin profiles of Gymnodinium inusitatum sp. nov., Gymnodinium catenatum and Gymnodinium microreticulatum (Dinophyceae) from the Yellow Sea, China. Harmful Algae 28: 97-107.

Gu, H., Luo, Z., Mertens, K. N., Price, A. M., Turner, R. E. and Rabalais, N. N. 2015. Cyst-motile stage relationship, morphology, ultrastructure, and molecular phylogeny of the gymnodinioid dinoflagellate Barrufeta resplendens comb. nov., formerly known as Gyrodinium resplendens, isolated from the Gulf of Mexico. J. Phycol. 51: 990-9.

Gu, H., Mertens, K. N. and Liu, T. 2016. Huia caspica gen. \& comb. nov., a dinoflagellate species that recently crossed the marine-freshwater boundary. Phycol. Res. 64: 251-8.

Hall, T. A. 1999. BioEdit: a user-friendly biological sequence alignment editor and an alysis program for Windows 95/98/NT. Nucleic Acids Symp. Ser. 41: 95-8.

Hansen, G., Botes, L. and De Salas, M. 2007. Ultrastructure and large subunit rDNA sequences of Lepidodinium viride reveal a close relationship to Lepidodinium 
chlorophorum comb. nov. (= Gymnodinium chlorophorum). Phycol. Res. 55: $25-41$.

Hansen, G., Daugbjerg, N. and Henriksen, P. 2000. Comparative study of Gymnodinium mikimotoi and Gymnodinium aureolum, comb. nov. (= Gyrodinium aureolum) based on morphology, pigment composition, and molecular data. J. Phycol. 36: 394-410.

Hansen, G. and Flaim, G. 2007. Dinoflagellates of the Trentino Province, Italy. $J$ Limnol. 66: 107-41.

Hansen, G., Moestrup, Ø. and Roberts, K. R. 2000. Light and electron microscopical observations on the type species of Gymnodinium, G. fuscum (Dinophyceae). Phycologia 39: 365-76.

Harris, T. 1940. A contribution to the knowledge of the British freshwater Dinoflagellata. Proc. Linn. Soc. Lond. 152: 4-33.

Hoppenrath, M., Bachvaroff, T., Handy, S., Delwiche, C. and Leander, B. 2009. Molecular phylogeny of ocelloid-bearing dinoflagellates (Warnowiaceae) as inferred from SSU and LSU rDNA sequences. BMC Evol. Biol. 9: 116-30.

Hoppenrath, M. and Leander, B. S. 2007. Morphology and phylogeny of the pseudocolonial dinoflagellates Polykrikos lebourae and Polykrikos herdmanae n. sp. Protist 158: 209-27.Kang, N. S., Jeong, H. J., Moestrup, Ø. et al. 2014. Gymnodinium smaydae n. sp., a new planktonic phototrophic dinoflagellate from the coastal waters of western Korea: morphology and molecular characterization. J. Eukaryot. Microbiol. 61: 182-203. 
Kang, N. S., Jeong, H. J., Moestrup, Ø. and Park, T. G. 2011. Gyrodiniellum shiwhaense n. gen., n. sp., a new planktonic heterotrophic dinoflagellate from the coastal waters of western Korea: morphology and ribosomal DNA gene sequence. J. Eukaryot. Microbiol. 58: 284-309.

Kang, N. S., Jeong, H. J., Moestrup, Ø. et al. 2010. Description of a new planktonic mixotrophic dinoflagellate Paragymnodinium shiwhaense n. gen., n. sp. from the coastal waters off western Korea: morphology, pigments, and ribosomal DNA gene sequence. J. Eukaryot. Microbiol. 57: 121-44.

Kim, K. Y., M. Iwataki, Kim, C. H. 2008. Molecular phylogenetic affiliations of Dissodinium pseudolunula, Pheopolykrikos hartmannii, Polykrikos cf. schwartzii and Polykrikos kofoidii to Gymnodinium sensu stricto species (Dinophyceae). Phycol. Res. 56: 89-92.

Kofoid, C. A. and Swezy, O. 1921. The free-living unarmored dinoflagellata. Vol. 5. University of California Press, Berkeley.

Kretschmann, J., Filipowicz, N. H., Owsianny, P. M., Zinssmeister, C. and Gottschling, M. 2015. Taxonomic clarification of the unusual Dinophyte Gymnodinium limneticum Wołosz. (Gymnodiniaceae) from the Tatra mountains. Protist 166: 621-37.

Larsen, J. 1994. Unarmoured dinoflagellates from Australian waters I. The genus Gymnodinium (Gymnodiniales, Dinophyceae). Phycologia 33: 24-33.

Levine, J. M. and D’Antonio, C. M. 1999. Elton revisited: a review of evidence linking diversity and invasibility. Oikos 87: 15-26 
Logares, R., Bråte, J., Bertilsson, S., Clasen, J. L., Shalchian-Tabrizi, K. and Rengefors, K. 2009. Infrequent marine-freshwater transitions in the microbial world. Trends Microbiol. 17: 414-22.

Logares, R., Rengefors, K., Kremp, A. et al. 2007a. Phenotypically different microalgal morphospecies with identical ribosomal RNA: a case of rapid adaptive evolution? Microb. Ecol. 53: 549-61.

Logares, R., Shalchian-Tabrizi, K., Boltovskoy, A. and Rengefors, K. 2007b. Extensive dinoflagellate phylogenies indicate infrequent marine-freshwater transitions. Mol. Phylogen. Evol. 45: 887-903.

Luo, Z., You, X., Mertens, K. N. and Gu, H. 2016. Morphological and molecular characterization of Tovellia cf. aveirensis (Dinophyceae) from Jiulong River, China. Nova Hedwigia 103: 79-94.

Mapletoft, H., Montgomery, M., Waters, J. and Wells, P. 1966. A new freshwater dinoflagellate. New Phytol. 65: 54-8.

Mertens, K., Rengefors, K., Ellegaard, M. and Moestrup, Ø. 2012. A review of recent freshwater dinoflagellate cysts: taxonomy, phylogeny, ecology and palaeocology. Phycologia 51: 612-9.

Mertens, K. N., Takano, Y., Yamaguchi, A. et al. 2015. The molecular characterization of the enigmatic dinoflagellate Kolkwitziella acuta reveals an affinity to the Excentrica section of the genus Protoperidinium. Syst. Biodivers. 13: 509-24. Moestrup, Ø., Hakanen, P., Hansen, G., Daugbjerg, N. and Ellegaard, M. 2014. On Levanderina fissa gen. \& comb. nov. (Dinophyceae) (syn. Gymnodinium 
fissum, Gyrodinium instriatum, Gyr. uncatenum), a dinoflagellate with a very unusual sulcus. Phycologia 53: 265-92.

Moestrup, Ø., Lindberg, K. and Daugbjerg, N. 2009. Studies on woloszynskioid dinoflagellates IV: The genus Biecheleria gen. nov. Phycol Res. 57: 203-20.

Nygaard, G. 1945. Dansk Planteplankton. Gyldendal, Copenhagen.Penard, E. 1891. Les Péridiniacées du Lac Léman. Bull.Trav. Soc. Bot. Genève 6: 1-63.

Posada, D. 2008. jModelTest: phylogenetic model averaging. Mol. Biol. Evol. 25: $1253-6$.

Reñé, A., Camp, J. and Garcés, E. 2015. Diversity and phylogeny of Gymnodiniales (Dinophyceae) from the NW Mediterranean Sea revealed by a morphological and molecular approach. Protist 166: 234-63.

Reñé, A., Satta, C. T., Garcés, E. et al. 2011. Gymnodinium litoralis sp. nov. (Dinophyceae), a newly identified bloom-forming dinoflagellate from the NW Mediterranean Sea. Harmful Algae 12: 11-25.

Rodriguez, F., Oliver, J., Marin, A. and Medina, J. R. 1990. The general stochastic model of nucleotide substitution. J. Theor. Biol. 142: 485-501.

Ronquist, F. and Huelsenbeck, J. P. 2003. MrBayes 3: Bayesian phylogenetic inference under mixed models. Bioinformatics 19: 1572-4.

Sampedro, N., Fraga, S., Penna, A. et al. 2011. Barrufeta bravensis gen. nov. sp. nov. (Dinophyceae): a new bloom-forming species from the northwest Mediterranean Sea. J. Phycol. 47: 375-92.

Scholin, C. A., Herzog, M., Sogin, M. and Anderson, D. M. 1994. Identification of 
group- and strain-specific genetic markers for globally distributed Alexandrium (Dinophyceae). II. Sequence analysis of a fragment of the LSU rRNA gene. J. Phycol. 30: 999-1011.

Skuja, H. L. 1956. Taxonomische und biologische Studien über das Phytoplankton Schwedischer Binnengewässer. Nova Acta Regiae Societatis Scientiarum Upsaliensis, Ser. IV 16: 1-404.

Skuja, H. 1964. Grundzüge der Algenflora und Algenvegetation der Fjellgegenden um Abisko in Schwedisch-Lappland. Nova Acta Reg. Soc. Scient. Upsaliensis, Ser. IV 18: $1-465$.

Stamatakis, A., Hoover, P. and Rougemont, J. 2008. A rapid bootstrap algorithm for the RAxML Web servers. Syst. Biol. 57: 758-71.

Stein, F. 1878. Die Organismus der Flagellaten. Leipzig, Verlag von Wilhelm Engelmann.

Sundström, A. M., Kremp, A., Daugbjerg, N. et al. 2009. Gymnodinium corollarium sp. nov. (Dinophyceae)-a new cyst forming cold-water dinoflagellate from the Baltic Sea; morphology, molecular phylogeny and ecophysiology. J. Phycol. 45: $938-52$.

Swift, E. 1973. Dissodinium pseudolunula n. sp. Phycologia 12: 90-1.

Takano, Y. and Horiguchi, T. 2006. Acquiring scanning electron microscopical, light microscopical and multiple gene sequence data from a single dinoflagellate cell. J. Phycol. 42: 251-6.

Takano, Y., Yamaguchi, H., Inouye, I., Moestrup, Ø. and Horiguchi, T. 2014. 
Phylogeny of five species of Nusuttodinium gen. nov. (Dinophyceae), a genus of unarmoured kleptoplastidic dinoflagellates. Protist 165: 759-78.

Takayama, H. 1985. Apical grooves of unarmored dinoflagellates. Bull. Plankton Soc. Jap. 32: $129-40$.

Tang, Y. Z., Egerton, T. A., Kong, L. and Marshall, H. G. 2008. Morphological variation and phylogenetic analysis of the dinoflagellate Gymnodinium aureolum from a tributary of Chesapeake Bay. J. Eukaryot. Microbiol. 55: $91-9$.

Thessen, A. E., Patterson, D. J. and Murray, S. A. 2012. The taxonomic significance of species that have only been observed once: the genus Gymnodinium (Dinoflagellata) as an example. PloS One 7: e44015.

Yuasa, T., Horiguchi, T., Mayama, S. and Takahashi, O. 2016. Gymnoxanthella radiolariae gen. et sp. nov. (Dinophyceae), a dinoflagellate symbiont from solitary polycystine radiolarians. J. Phycol. 51: 89-104. 
Figs 1-6. Light microscopy (LM) of vegetative cells of Gymnodinium plasticum strain TIO826. 1. Ventral view showing the sulcus. 2. A two-cell chain. 3. Ventral view showing the elongated nucleus (n) and several chloroplasts (c). 4. The same cell in fig. 3 with different focus showing the peripheral chloroplasts (c) connections (arrows). 5. Ventral view showing a presumable pyrenoid (arrow) and eyespot (e). 6. A DAPI-stained cell, showing the elongated nucleus (n).
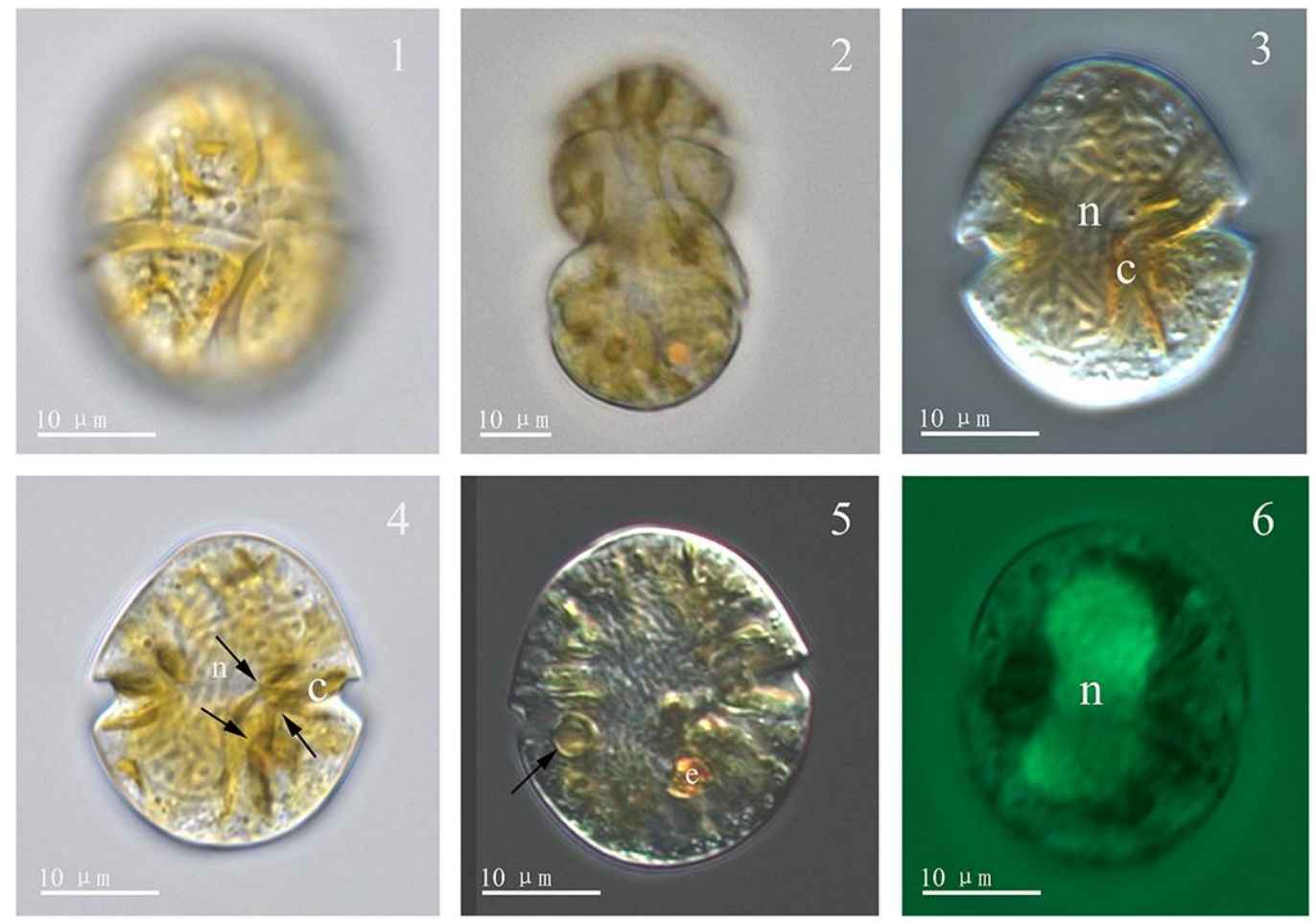

Figs 7-13. Scanning electron microscopy (SEM) of vegetative cells of Gymnodinium plasticum strain TIO826. 7. Left lateral view showing the projection of right epicone. 8. Apical view showing the sulcal intrusion and the apical structure complex. 9.

Several amphiesmal pores in the dorsal epicone. 10. Lateral view showing the sulcal intrusion and polygonal vesicles on the epicone. 11. Lateral view showing polygonal vesicles on the cingulum and hypocone. 12. Detail of the apical structure complex 
showing two prominent ridges and a deep groove inside. 13. Detail of the apical structure complex showing small knobs in the outer ridge (arrows).
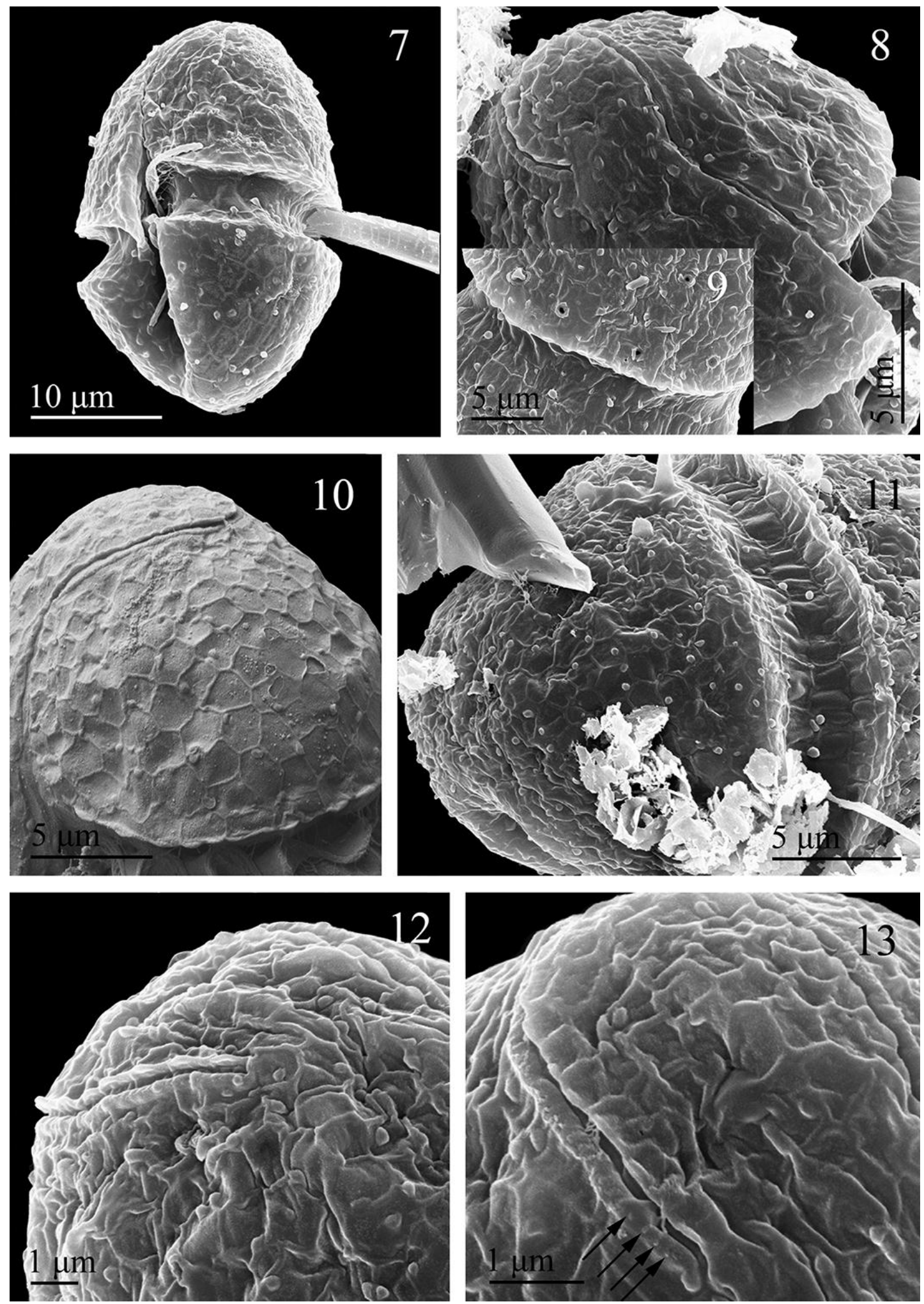
Fig. 14. Schematic illustration of the apical structure complex of Gymnodinium plasticum.

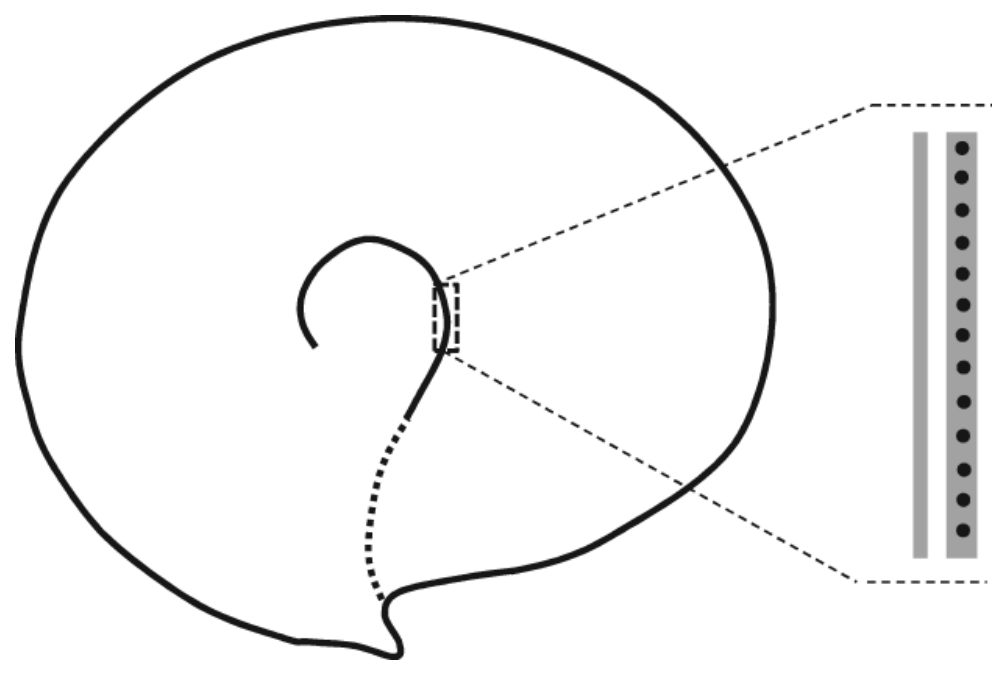


Figs 15-20. Light microscopy (LM) and scanning electron microscopy (SEM) micrographs of live cysts of Gymnodinium plasticum. 15 . Ventral view of the cyst yielding strain TIO826, showing a wide cingulum and a pronounced red accumulation body (ab) in the hypocyst (LM). 16. Ventral view of a cyst from the field, showing a round nucleus (n) (LM). 17. Lateral view of a cyst from the field, showing the rectangular shape (LM). 18. Apical view of a cyst from the field, showing the trapezoidal shape. 19, 20. Cysts formed in culture of strain TIO826, showing the wide cingulum (C) (SEM).
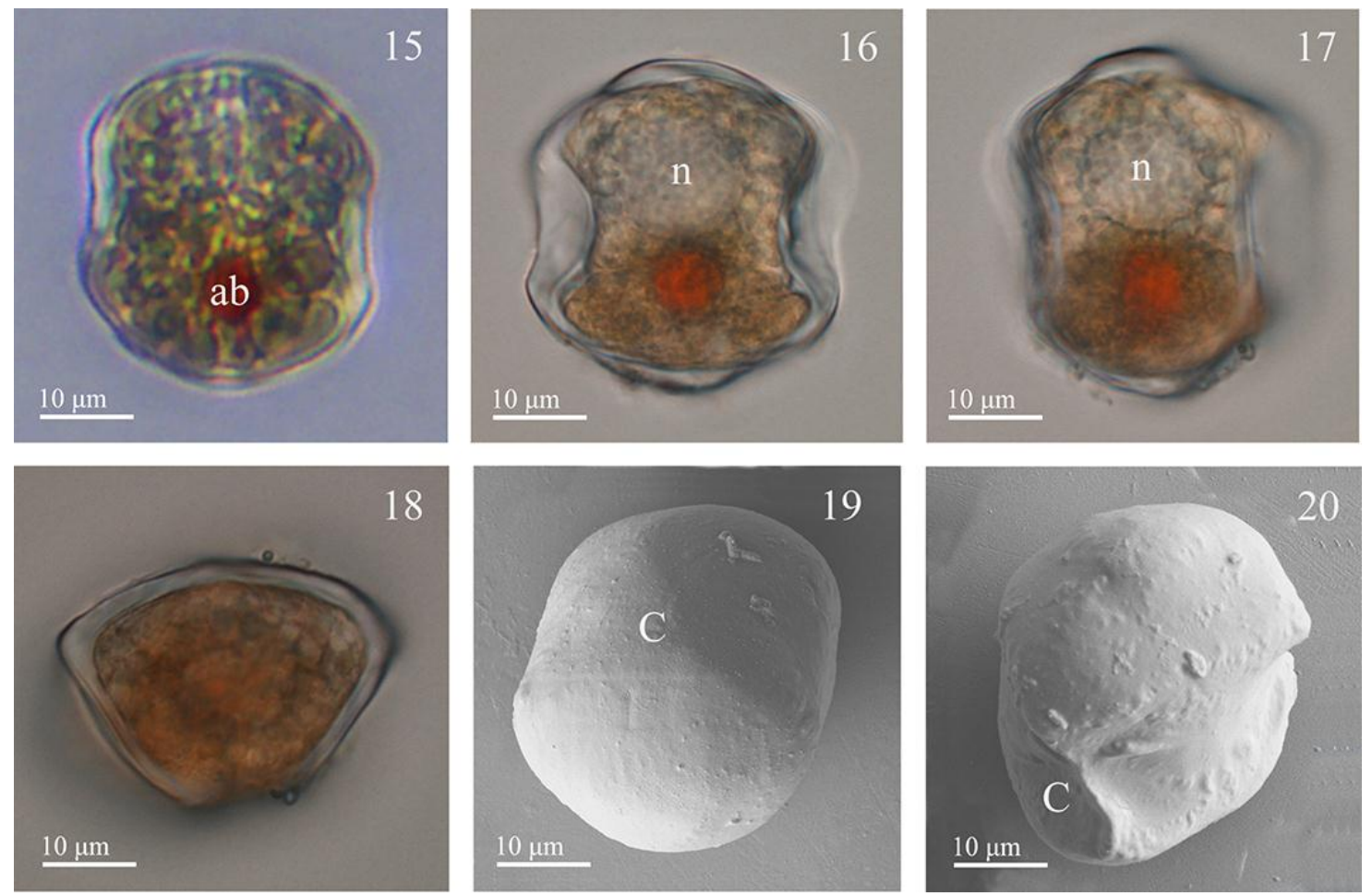
Fig. 21. Phylogeny of Gymnodinium plasticum inferred from concatenated data of small subunit, partial large subunit rDNA and internal transcribed spacer sequences using Bayesian inference (BI). Branch lengths are drawn to scale, with the scale bar indicating the number of nt substitutions per site. Dashed lines indicate half of the length. Numbers on branches are statistical support values to clusters on the right of them (left: Bayesian posterior probabilities; right: maximum likelihood bootstrap support values). Posterior probability $(>0.9)$ for BI support/Bootstrap value $(>50 \%)$ for maximum likelihood (ML) are shown. * indicates maximal support (BI posterior probability $=1.00 /$ ML bootstrap support $=100$ ). New sequences are indicated in bold with the order of SSU, ITS and LSU. 
Noctiluca scintillans GQ380592

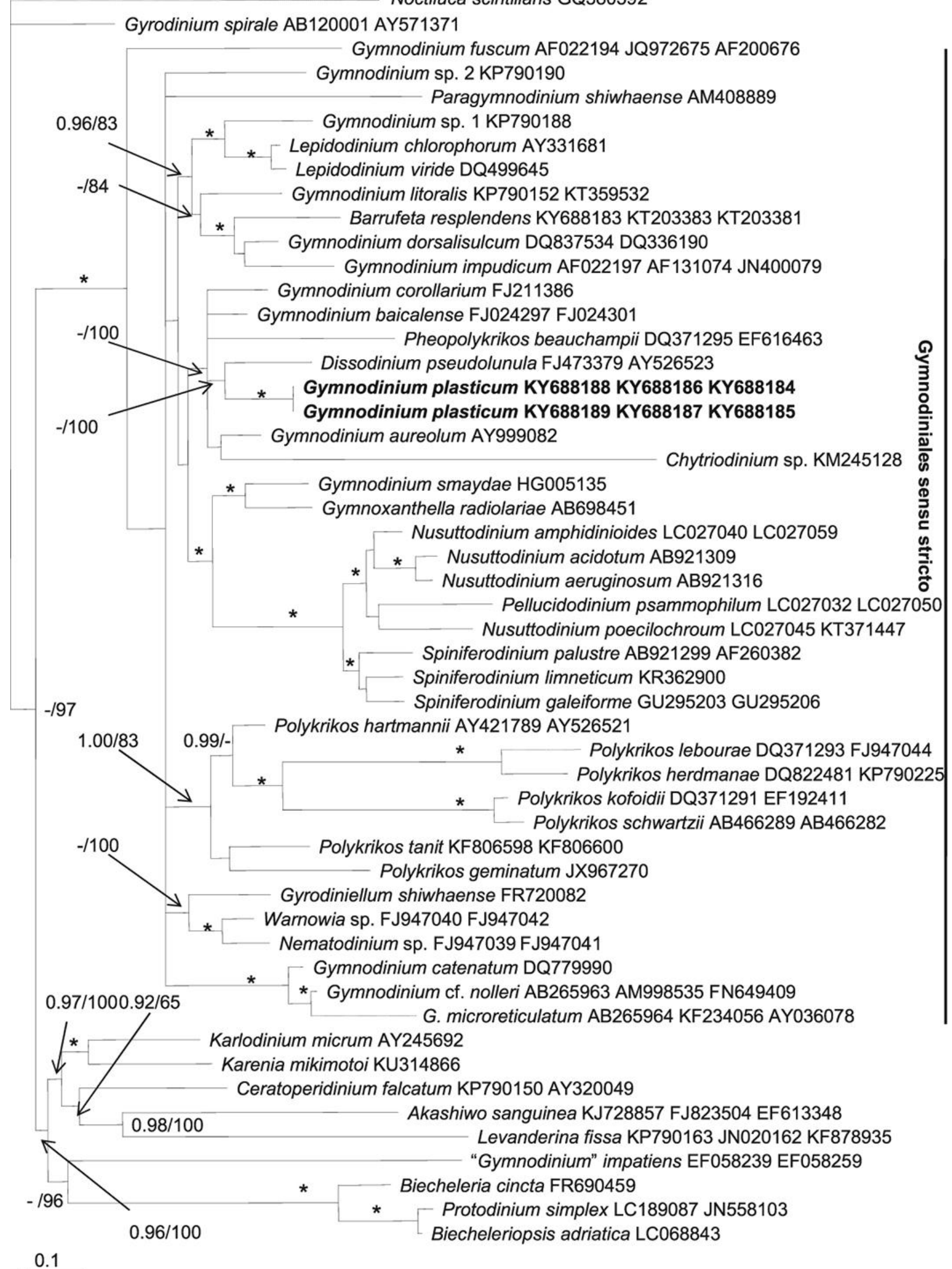


Table 1. Morphological comparisons of Gymnodinium plasticum with related species (N.A. = not available)

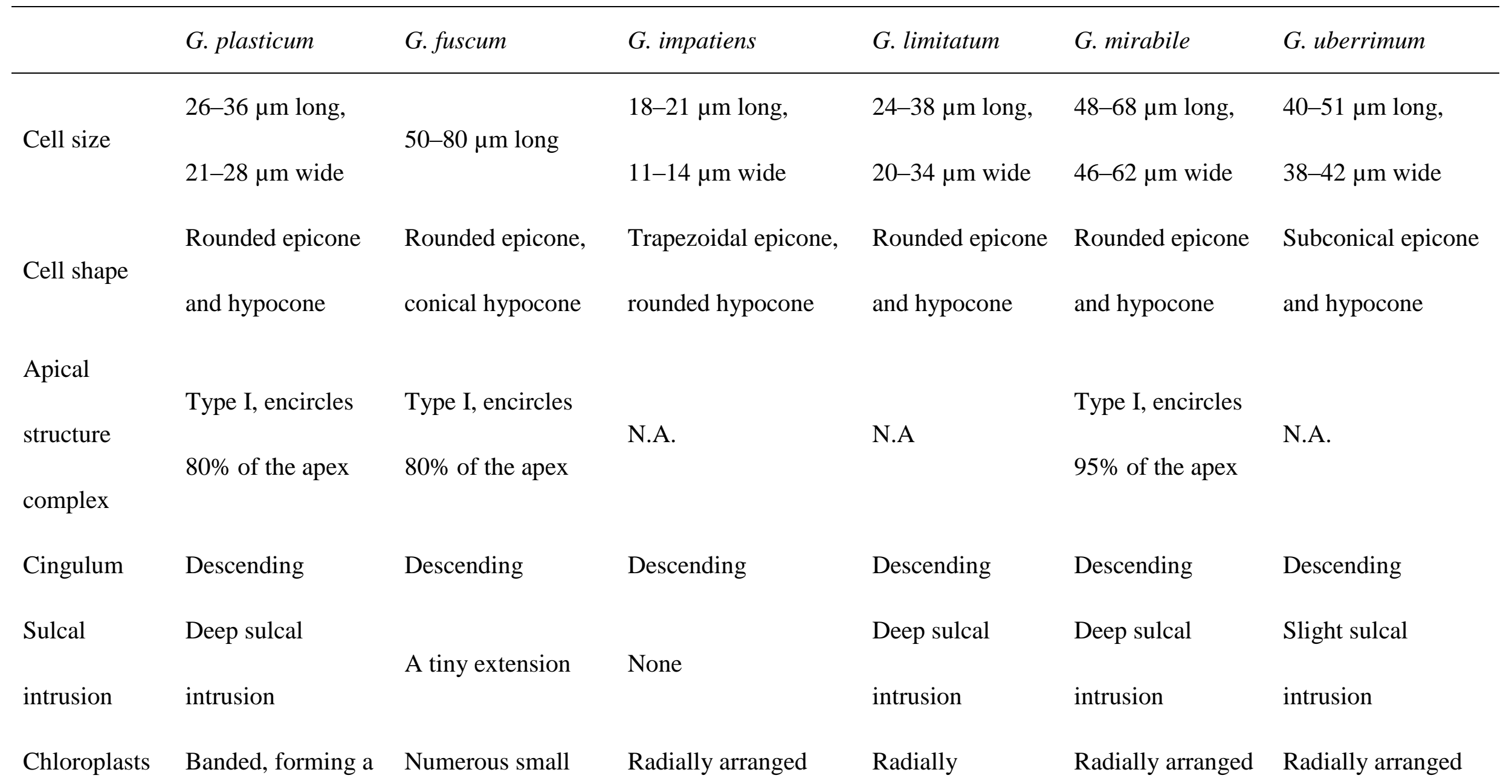




\begin{tabular}{|c|c|c|c|c|c|c|}
\hline & network & elongate & & arranged & & \\
\hline Nucleus & $\begin{array}{l}\text { Elongated running } \\
\text { nearly vertically }\end{array}$ & Spherical & Spherical & Spherical & Spherical & $\begin{array}{l}\text { Spherical or } \\
\text { ellipsoidal }\end{array}$ \\
\hline Cyst size & $\begin{array}{l}\text { 31-41 } \mu \mathrm{m} \text { long, } \\
28-35 \mu \mathrm{m} \text { wide }\end{array}$ & $40 \mu \mathrm{m}$ in diameter & $\begin{array}{l}\text { 18-20 } \mu \mathrm{m} \text { long, } \\
13-14 \mu \mathrm{m} \text { wide }\end{array}$ & N.A. & N.A. & N.A. \\
\hline Cyst shape & $\begin{array}{l}\text { Rounded epicyst } \\
\text { and hypocyst }\end{array}$ & Spherical & Ellipsoidal & Spherical & N.A. & N.A. \\
\hline Reference & Present study & Hansen et al. 2000 & Skuja 1964 & Skuja 1956 & $\begin{array}{l}\text { Pénard 1891; } \\
\text { Hansen } 2007\end{array}$ & $\begin{array}{l}\text { Allman } 1855 ; \\
\text { Kofoid \& Swezy } \\
1921\end{array}$ \\
\hline
\end{tabular}

